〔26〕アイソタクチックポリプロピレンと無水マレイン酸との反応,

およびそのイオン橋かけ反応

第 2 報 均一系比打る反応

(1967 年 3 月 20 日受理)

井手文雄 ${ }^{*}$. 児玉恒雄 ${ }^{*}$. 長谷川 章*

\begin{abstract}
要 旨 溶融索䴔反応によってアイソタクチックポリプロピレン中への高分子反応による無水マレ イン酸の期入，扣よびイオン橋かけ反応が可能であることは前報に示したごとくであるが，この場合， 重合波の低下をおさえることができない。そこで適当な溶媒中での均一反応について検討したところ次 のよらな萑果を得た。

1）アイソタクチックポリプロピレンへの無水マレイン酸の導入反応は, キシレン溶媒中にアイソタ クチックポリプロピレンおよび無水マレイン酸を均一に分散させ，窒索下 $120^{\circ} \mathrm{C}$ に年温後，開始剤， たとえば過酸化ベンゾイルを加えてゆくと容易に起こる。

2）得られたベースポリマーは，未変性のポリプロピレンに比べて重合度の低下が少なく，また，無 水マレイン酸に帰因する着色の見られない無色の粉末状で得られる。

3）イオン橋かけ反応はトルエンとジチルホルムアミドの混合溶媒中で酢酸亜鉛を用いることによ って容易に行ならことができる。
\end{abstract}

\section{1. 緒言}

ポリプロピレンなどの $\alpha$ オレフィン系ポリマーにつ いては前報”に示したごとく，溶融素㸚り反応によって 筧水マレイン酸を高分子反応させ, しかる後に金属塩と 反応させればイオン橋かけが導入できる。この場合, 高 温下で素祊りを行ならためにポリマーの重合度の著しい 低下をさけることができない。重合度が低下寸るという ことはポリマーの機械的性質の低下を導くことになるの でより高い重合度を有する反応ポリマーを合成するた めに, 適当な溶媒中における反応について検討を行なっ た。このような均一系反応に関しては箕浦らが主として アタクチックポリプロピレンに無水マレイン酸を導入 し，イオン橋かけ反応が可能であることを筆者らと相前 後して発表している2”。また, アルミニウムなどの金属 薄板にポリプロピレンあるいは，ポリエチレンなどを涳 装するさいに，その中間層に，脂肪族炭化水素や芳香族 炭化水素溶媒中で合成した無水マレイン酸変性ポリプロ ピレンが用いられたとの報告3'がある。

䇥者らは独自の立場で結晶性のアイソタクチックポリ プロピレンに無水マレイン酸を導入する方法について検 討し, その可能性を見出すとともに, さらにイオン橋か け反応について検討を行なった。本報告はそれらの反応 の基礎的な因果関係を明らかにしたものである。

*三菱レイヨン株式会社研究所高分子研究室（広島県 大竹市御幸町 20 の 1 )

\section{2. 実験方法}

\section{1 試 薬}

アイソタクチックポリプロピレン (IPP) は三菱油化 製 $\operatorname{IPP}([\eta]=1.96)$ を 60 ～ 80 メッシュに粒度をそろ え, 無水マレイン酸 (MAH), 過酸化ベンゾイル (BPO) は通常法にて再結晶させ, 橋かけ剤として用いた酢酸亜 鈆 $\left(\mathrm{Zn}(\mathrm{OAc})_{2}\right)$ は市販品をそのまま用いた。キシレ ン, アセトン, トルェンおよびジメチルホルムアミト (DMF) は通常法にて蒸留を行ない, 水はイオン交換水 を用いた。

\subsection{IPPへの MAH 導入反応}

窒素流通下, 四径フラスコあるいはセパラブルフラス コ中に精製キシレン, IPPおよび $\mathrm{MAH}$ を仕込み, 常温 にて $30 \mathrm{~min} \sim 1 \mathrm{hr}$ 激しくかきませ，定常後 $120^{\circ} \mathrm{C}$ に昇 温した。IPPが完全に透明になりキシレン中に溶解した 後に, キシレンに浴かした BPO を滴下し,さらに 4 時間 反応を継続させた。反応終了倓, 反応溶液の温度が 80 $100^{\circ} \mathrm{C}$ のちに反応液をアセトン中に流しこみ, かきま ぜ後, 口過乾燥し, さらにこのポリマーをアセトンで再 び十分に抽出して IPP 中に含有される末反応 $\mathrm{MAH}$ を 完全に除去した。

\section{3 イオン橋かけ反応}

槅かけ剂は $\mathrm{Zn}(\mathrm{OAc})$ 2を用い，溶媒としては非極性 であり橋かけポリマーが安定に存在すると思われるトル エンを選び, トルェンと相溶し $\mathrm{Zn}(\mathrm{OAc})_{2}$ が可溶であ るといら点でDMFを 8/2 (重量比) の割合で用いた。

窒素流通下, 4 径あるいは七バラブルフラスコ中にト 
ルエン, $\mathrm{DMF}, \mathrm{Zn}(\mathrm{OAc})_{2}$ およびペースポリマーを仕 込之, 容器内の定常後, 反応容器を $80^{\circ} \mathrm{C}$ に昇温し $1 \sim$ 3 時間かきまぜる。反応終了後, ポリマーを口過乾燥し, さらにア七トン混合溶媒にて抽出し, 未反応 $\mathrm{Zn}(\mathrm{OAc})_{2}$ を除去した。

\section{4 評価法}

前報りに準ずる。

\section{3. 実験結果ならびに考察}

\subsection{IPP への MAH 導入反応}

\subsubsection{IPP-MAH 反応の確認}

開始剤としてBPO を用いて反応させたポリマーを充 分にアセトン抽出して未反応 $\mathrm{MAH}$ を除去した後, フィ ルム状にしてその赤外吸収スペクトルを調べると，1770 $\mathrm{cm}^{-1}, 1785 \mathrm{~cm}^{-1}, 1860 \mathrm{~cm}^{-1}$ に酸無水物による $\mathrm{MAH}$ 特珄ピークが出現する(Fig. 1，No. 3)。開始剤を用いた ときと用い始とさ反応ポリマーのアセトン抽出前後の 赤外吸収スペクトルの傾向は Fig. 1 のごとくである。 $\mathrm{MAH}$ はキシレン中に密に存在しているため, $120^{\circ} \mathrm{C} て ゙$ 容解しているIPP の冷却過程中に, 未反応 MAH モノマ ーがブレンドされるが，これはアセトン抽出によって十 分に除去されることがわかる。したがって開始剤を用い て反応させたポリマーの赤外吸収スペクトルにおいて, $1770 \mathrm{~cm}^{-1}, \quad 1785 \mathrm{~cm}^{-1}, \quad 1860 \mathrm{~cm}^{-1}$ に出現した酸無水物

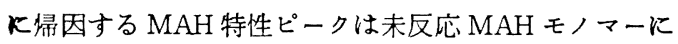
よるものではない。また種々の条件で反応させたポリマ

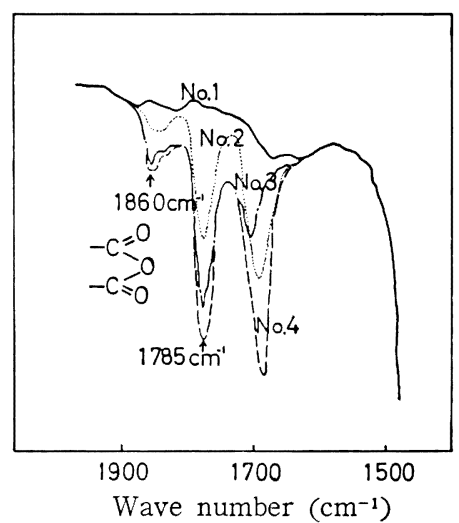

No. 1 ( $\longrightarrow$ ) : after extraction of the product reacted without $\mathrm{BPO}$.

No. $2(\cdots \cdots)$ : before extraction of the product reacted without $\mathrm{BPO}$.

No. 3 (- - ) : after extraction of the reaction product between IPP and MAH.

No. 4 (-) : before extraction of the reaction product between IPP and MAH.

Fig. 1. IR spectra of the products before and after extraction with xylene.

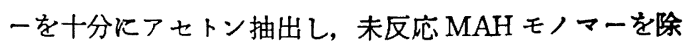
去したときの赤外吸収スペクトルの傾向は Fig. 2 のご とくであった。

すなわち, 衝突の確率が高く, BPO のラジル寿命が 最も有効に活かされる方向に IPP と MAH との反応が 進行してゆくことがわかる。以上の事実はいずれもIPP へMAHが導入されたことを重ずけるものである。さら に $\mathrm{Zn}(\mathrm{OAc})_{2}$ を用いてイオン橋かけさせたポリマーのキ

Table 1. Gel contents of ionic crosslinked products under various conditions.

\begin{tabular}{c|c|c|c|c}
\hline \hline $\begin{array}{c}\text { Run } \\
\text { No. }\end{array}$ & $\begin{array}{c}{[\mathrm{BPO}]} \\
(\mathrm{mol} \%)\end{array}$ & $\begin{array}{c}{[\mathrm{MAH}]} \\
(\mathrm{mol} \%)\end{array}$ & $\begin{array}{c}\mathrm{Zn( \textrm {OAc } )} \\
(\mathrm{mol} \%)\end{array}$ & $\begin{array}{c}\text { Gel content } \\
(\%)\end{array}$ \\
\hline 1 & 0 & 0 & 0 & 0 \\
2 & 0.86 & 0 & 0 & 0 \\
3 & 0.86 & 14.6 & 0 & 0 \\
4 & 0.86 & 14.6 & 0.39 & 80 \\
5 & 0.86 & 0 & 0.39 & 0 \\
6 & 0 & 0 & 0.39 & 0 \\
\hline
\end{tabular}

Gel content: The residue of Soxhlet extraction at $140^{\circ} \mathrm{C}$ for $24 \mathrm{hrs}$ with xylene.

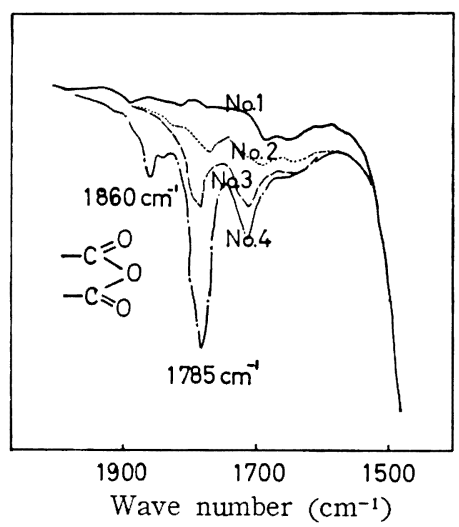

No. $1:$ IPP, IPP and BPO or IPP and MAH were added in xylene and the solution was heated to $120^{\circ} \mathrm{C}$.

No. 2 : IPP, BPO and MAH were added in xylene at the same time, and the solution was heated to $120^{\circ} \mathrm{C}$.

No. $3: \mathrm{BPO}$ and $\mathrm{MAH}$ were added after the temperature of the solution of xylene and IPP reacted about 120 ${ }^{\circ} \mathrm{C}$.

No. 4 : BPO was added after the temperature of the solution of IPP, MAH and xylene reached about $120^{\circ} \mathrm{C}$, where MAH could exist richly around IPP.

Fig. 2. IR spectra of the products reacted under various conditions. 
シレンによる溶解テストを行なったところ， IPP $\times \mathrm{BPO}$ $\times \mathrm{MAH} \times \mathrm{Zn}(\mathrm{OAc})_{2}$ の系だけにゲルの存在が認められ た (T able 1)。MAH 分子が IPP 中に橋かけ座席とし て導入されていないかぎりキシレンに溶解するはずであ る。以上の諸事実より, IPP 分子中に $\mathrm{MAH}$ 分子が導入 されたことを確認した。

\subsubsection{MAH 反応量の定量化}

前報1 に述べたごとく定量化には赤外吸収スペクトル を用い, $1785 \mathrm{~cm}^{-1}$ の MAH 特性ピークと $840 \mathrm{~cm}^{-1}$ の基 準ピークとの吸光比の傾向をみた。検量線は前報1) と同 一の方法で作成し，MAH 反応量を算出した。

\section{1 .3 反応条件と MAH 反応との関係}

a. MAH 濃度および BPO 濃度と MAH 反応量およ び $[\eta]$ との関係

$\mathrm{MAH}$ 濃度関係怙よび $\mathrm{BPO}$ 濃度と MAH 反応量拈よ び $[\eta]$ との関係を Fig. 3，Fig. 4 亿示す。 MAH 反応 量は $\mathrm{BPO}$ 濃度および MAH 濃度に比例して増加する。

[n] の傾向をみると, MAH が存在しないときは $\mathrm{BPO}$ はポリマーの $[\eta] に$ に影響を及ぼさない(Fig. 3)。これは BPO による主鎖の切断反応が起こらないことを意味す るものである。この場合, BPO ラジカルはキシレンの連 鎖移動と IPP 主鎖の第三級水素の引抜きなどに消費さ れると考えられる。反応温度が低いため, 生成した IPP ラジカルは分解淿働くよりも，ラジカルの安定性からみ て, キシレンと反応あるいは BPO の連鎖移動によって

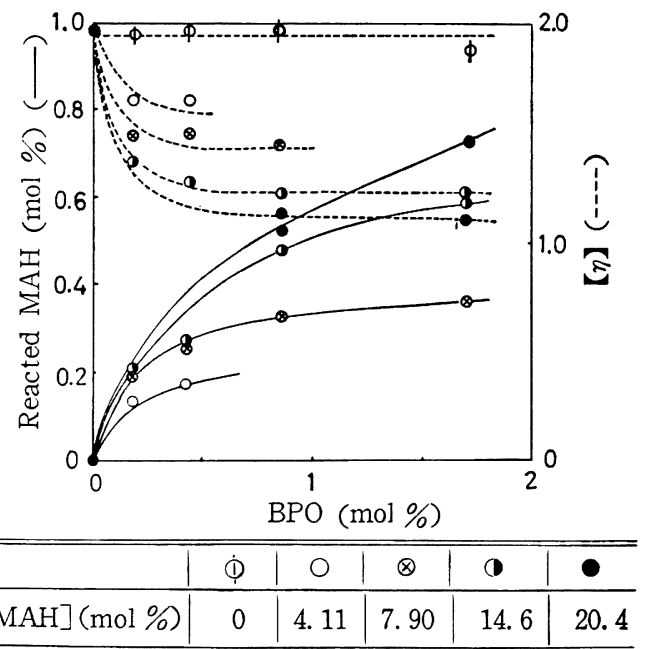

IPP : $[\eta]_{0}=1.96$

IPP concentration in xylene $: 100 \mathrm{~g} / l$

reacted at $120^{\circ} \mathrm{C}$ for 4 hours in $\mathrm{N}_{2}$

Fig. 3. Effect of BPO concentration on the amount of reacted MAH and $[\eta]$ of the products reacted with $\mathrm{MAH}$ of various concentrations.
生じたベンジルラジカルなどと反応して安定化するので あろら。また, IPP-MAH 反応ポリマーの [n]は BPO 濃度に依存するよりも $\mathrm{MAH}$ 濃度に依存して低下する傾 向を示す。そこで $\mathrm{MAH}$ 反応量と $[\eta]$ との関係を調べる

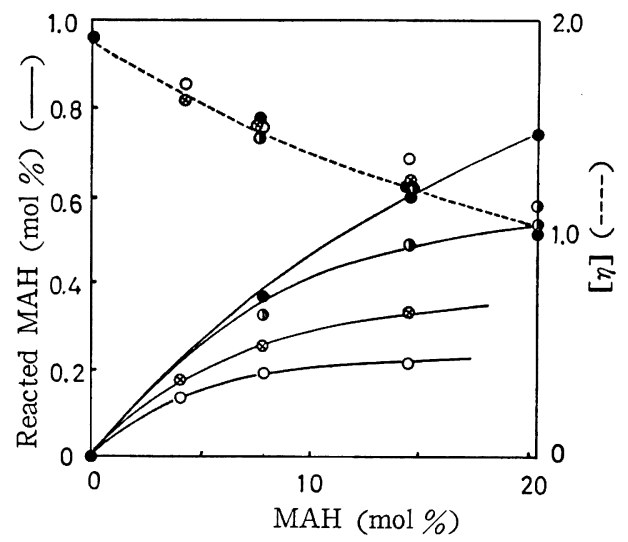

\begin{tabular}{c|c|c|c|c}
\hline \hline & 0 & $\otimes$ & $\bullet$ & $\bullet$ \\
\hline$[\mathrm{BPO}](\mathrm{mol} \%)$ & 0.17 & 0.43 & 0.86 & 1.70 \\
\hline
\end{tabular}

IPP $:[\eta]_{0}=1.96$

IPP concentration in xylene $: 100 \mathrm{~g} / \mathrm{l}$ reacted at $120^{\circ} \mathrm{C}$ for 4 hours in $\mathrm{N}_{2}$

Fig. 4. Effect of MAH concentration on the amount of reacted MAH and $[\eta]$ of the products reacted with BPO of various concentrations.

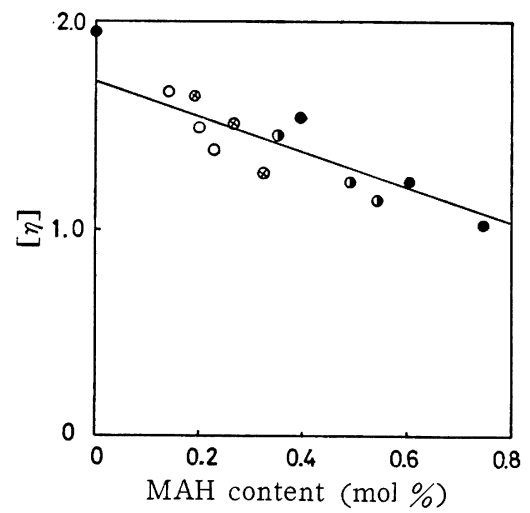

\begin{tabular}{c|c|c|c|c}
\hline \hline & 0 & $\otimes$ & 0 & $\bullet$ \\
\hline$[\mathrm{BPO}](\mathrm{mol} \%)$ & 0.17 & 0.43 & 0.86 & 1.70 \\
\hline
\end{tabular}

IPP $:[\eta]_{0}=1.96$

IPP concentration in xylene $: 100 \mathrm{~g} / \mathrm{l}$ reacted at $120^{\circ} \mathrm{C}$ for 4 hours in $\mathrm{N}_{2}$

Fig. 5. Effect of MAH content on $[\eta]$ of the reaction products between IPP and MAH. 
と, Fig. 5 のごとくほぼ一次の関係になることがわか る。すなわち, この場合の反応ポリマーの $[\eta]$ の低下は BPO による主鎖の切断によるものではなく，IPP 中に側 鎖として導入された $\mathrm{MAH}$ 分子が反応ポリマーの粘性挙 動に影響を及ぼした結果と考えられる。

b. 反応時間および反応温度と MAH 反応量および $[\eta]$ との関係

MAH 反応量と反応時間扣よび反応温度との関係を Fig. 6, Fig. 7 に示す。IPP への MAH 導入反応は 30 min 1 hr で終了し，また，反応温度に大きく依存する ことがわかる。

[ $\eta$ ] と反応温度との関係は Fig. 7 のごとくである。 また，反応速度の対数と反応温度の逆数とをプロットす

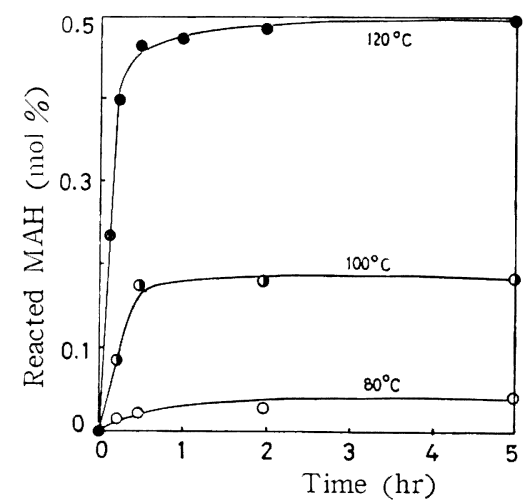

[BPO] : $0.860 \mathrm{~mol} \%$, [MAH] : $14.6 \mathrm{~mol} \%$ IPP concentration in xylene $: 100 \mathrm{~g} / l$

Fig. 6. Effect of reaction time on the amount of reacted $\mathrm{MAH}$.

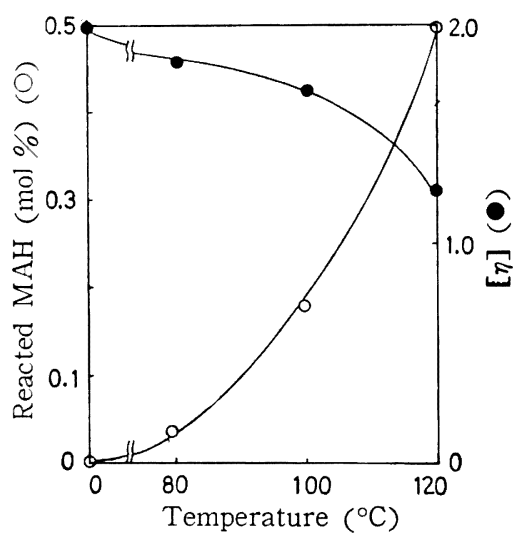

[BPO] : $0.860 \mathrm{~mol} \%,[\mathrm{MAH}]: 14.6 \mathrm{~mol} \%$ IPP concentration in xylene $: 100 \mathrm{~g} / l$ reacted for 5 hours in $\mathrm{N}_{2}$

Fig. 7. Effect of reaction temperature on the amount of reacted $\mathrm{MAH}$ and $[\eta]$ of the products.
ると Fig. 8 のごとくであって, IPP と MAH との反応 の見かけの活性化エネルギーは $22.9 \mathrm{kcal} / \mathrm{mol}$ であっ った。

\section{2 イオン橋かけ反応}

\subsection{1 イオン橋かけ反応の確認および定量}

前報1に準ずる。

\section{2.2 橋かけ剤濃度}

橋かけ剤としては溶融素㸚り法において最も顕著な効 果を示した $\mathrm{Zn}(\mathrm{OAc})_{2}$ を用いた。 $\mathrm{Zn}(\mathrm{OAc})_{2}$ を用いて トルェン - DMF 混溶媒中で橋かけ処理したポリマーの

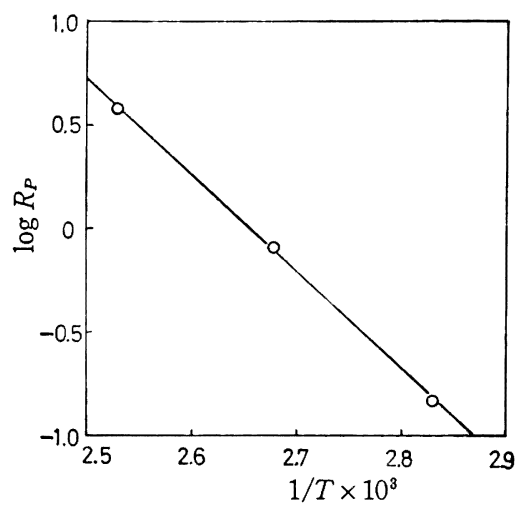

The overall activation energy of the reac. tion of IPP and MAH was calculated as about $22.9 \mathrm{kcal} / \mathrm{mol}$.

Fig. 8. The plot of $\log R_{P}$ vs. $1 / T$.

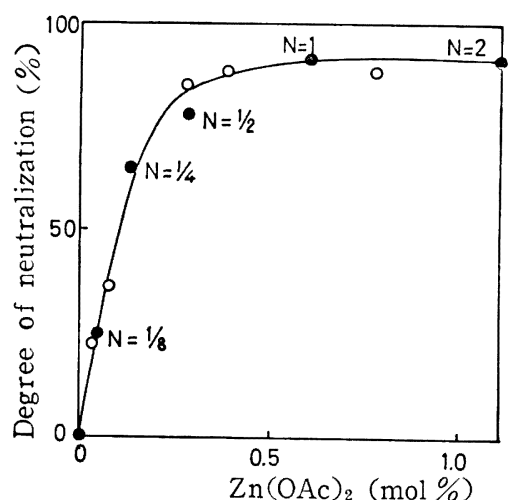

Base polymer $\mathrm{O}: \mathrm{MAH}$ content $=0.78 \mathrm{~mol} \%$

- $: \mathrm{MAH}$ content $=1.12 \mathrm{~mol} \%$

crosslinked at $80^{\circ} \mathrm{C}$ for 4 hours

Toluene/DMF/Base polymer $=16 / 4 / 1$ (by weight)

$N$ : the equivalent ratio of $\mathrm{Zn}(\mathrm{OAc})_{2}$ to the amount of reacted $\mathrm{MAH}$

Fig. 9. Effect of $z$ inc acetate concentration on the degree of neutralization. 
中和度と橋かけ剤濃度との関係を Fig. 9 に示す。橋か け剤濃度が含有酸基の $1 / 2$ 倍当量以下では, 中和反応は 橋かけ剤濃度に比例しており，1 倍当量を越えると定常 值を示す。このように仕込橋かけ剤濃度がほぼ理論量に 等しいことは，橋かけ反応が溶液中の反応であるため, 橋かけ剤が拡散しやすく，かつ，反応温度が比較的低い ために，反応中での逃散が起こらぬなどの理由で，きわ めて効率良く橋かけが進行するためであろう。

Fig. 10 は赤外吸収スペクトルから計算されたカルボ キシレートの吸光比の增加, および $\mathrm{MAH}$ 特性のピーク の減少の割合を橋かけ風濃度に対しプロットしたもので ある。両者の增加の割合と減少の割合はほぼ相対してお り，溶融素祸り反応において見られたごとく"カルボキ シレートの生成の割合の方が大きくなるといらことはな い。これは均一系の反応温度がより低いために, 橋かけ に寄与しないイオン反応生成物が溶融素ねり反応に比べ て生成しにくいためと考えられるが，その理由について は明らかでない。

\subsection{3 橋かけ時間および橋かけ温度}

橋かけ反応の反応時間拉よび反応温度依存性を調べる ために，中和度との関係を調べた結果を Fig. 11に示す。 橋かけ反応はきわめて速く起こり，しかも温度に依存し ない。この場合の橋かけ反応の見かけの活性化エネルギ 一はほぼ0に等しい。

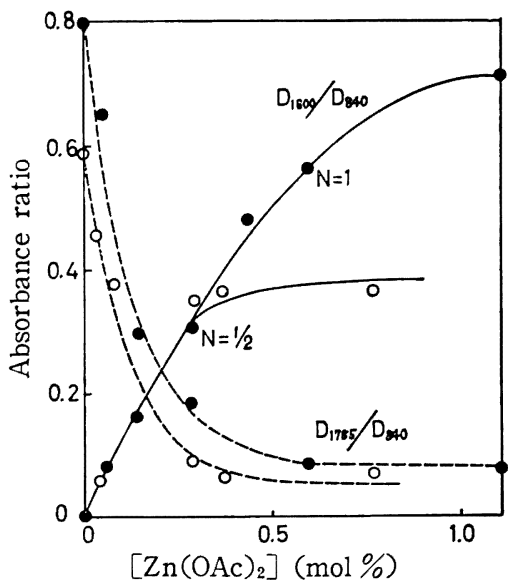

Absorbance : $1785 \mathrm{~cm}^{-1}=\mathrm{MAH}$ peak, $1600 \mathrm{~cm}^{-1}={ }^{-C^{-}}{ }^{-}$peak

Base polymer

$$
\mathrm{O}: \text { reacted } \mathrm{MAH}=0.78 \text { mole } \%
$$

- : reacted $\mathrm{MAH}=1.12 \mathrm{~mole} \%$

crosslinked at $80^{\circ} \mathrm{C}$ for 4 hours

$N$ : the equivalent ratio of $\mathrm{Zn}(\mathrm{OAc})_{2}$ to the amount of reacted $\mathrm{MAH}$

Fig. 10. Effect of zinc acetate concentration on the degree of ionic crosslinking.

\section{3 溶融素ねり反応と溶液中での反応との比較}

以上のようにキシレン中での均一反応によるIPP と $\mathrm{MAH}$ との反応, 扰よびトルェン - DMF 中でのイオン橋 かけ反応が可能であることが明らかとなった。そこで, このような溶液中での反応についてその特徴をさらに明 確にするために，前報”に述べたような溶融素初り反応 によるものとの比較を行なってみた。Table 2 および Table 3 はきわめて模式的にその性状の比較を行なっ たものである。すなわち，高温下の素対り反応であるため に不均一系の $[\eta]$ は主鎖の切断が進行し，きわめて低下 するが比較的低温でかつ機峨的切断などの因子のない均 一釆においては反応ポリマーの[ク]は汪とんど低下しな

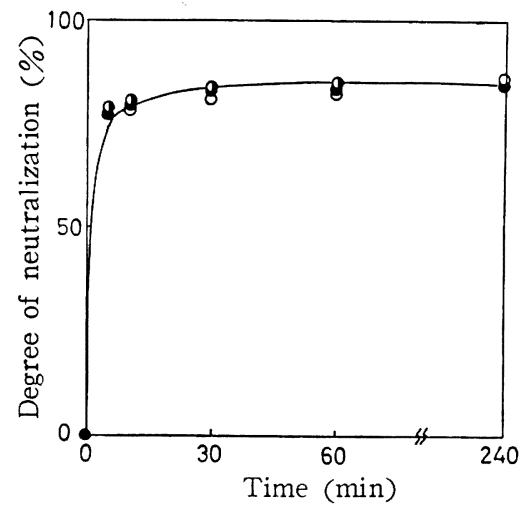

Base polymer : $\mathrm{MAH}$ content $=0.78 \mathrm{~mol} \%$ $\left[\mathrm{Zn}(\mathrm{OAc})_{2}\right]: 0.39 \mathrm{mo} \%$

\begin{tabular}{l|c|c|c}
\hline \hline & 0 & $\bullet$ & 0 \\
\hline Reaction temperature $\left({ }^{\circ} \mathrm{C}\right)$ & 25 & 50 & 80 \\
\hline
\end{tabular}

Fig. 11. Effect of reaction time on the degree of neutralization at various reaction temperatures.

Table 2. The comparison of the reaction between IPP and MAH in molten state and that in solvent.

\begin{tabular}{|c|c|c|c|}
\hline & & $\begin{array}{l}\text { Reaction in } \\
\text { molten state }\end{array}$ & $\begin{array}{l}\text { Reaction in } \\
\text { solvent }\end{array}$ \\
\hline \multicolumn{2}{|r|}{$E^{*}$} & $<0$ & $22.9 \mathrm{kcal} / \mathrm{mol}$ \\
\hline \multirow{3}{*}{$\begin{array}{l}\text { Nature } \\
\text { of the } \\
\text { product }\end{array}$} & {$[\eta]$} & low & high \\
\hline & $N_{M}$ & small & large \\
\hline & appearance & $\begin{array}{l}\text { colored, } \\
\text { massive }\end{array}$ & $\begin{array}{l}\text { uncolored, } \\
\text { powder }\end{array}$ \\
\hline
\end{tabular}

$E^{*}:$ the overall activation energy of the reaction between IPP and MAH.

$N_{\boldsymbol{M}}$ : the average number of reacted $\mathrm{MAH}$ in one polymer chain. 
Table 3. The comparison of jonic crosslinking reacted in molten state and that in solvent.

\begin{tabular}{c|c|c|c}
\hline \hline & $\begin{array}{l}\text { Reaction in } \\
\text { molten state }\end{array}$ & $\begin{array}{c}\text { Reaction in } \\
\text { solvent }\end{array}$ \\
\hline$E^{*}$ & $2.9 \mathrm{kcal} / \mathrm{mol}$ & 0 \\
\hline$A$ & much & little \\
\hline $\begin{array}{c}\text { Nature } \\
\text { of the } \\
\text { product }\end{array}$ & $\begin{array}{c}\text { Gel } \\
\text { content }\end{array}$ & little & much \\
\cline { 2 - 3 } & appearance & $\begin{array}{c}\text { colored, } \\
\text { massive }\end{array}$ & $\begin{array}{l}\text { uncolored, } \\
\text { powder }\end{array}$ \\
\hline
\end{tabular}

$E^{*}$ : the ovaral] activation energy of ionic crosslinking.

$A$ : The amount of byproduct which was obtained by the reaction between the carboxylic acid unit in the polymer and the acetate unit coming from zinc acetate, not by the reaction between two carboxylic units in the polymers.

い。したがって IPP 1 分子に反応する MAH の平均個数 $N_{M}$ は重合度の高い均一系が多くなり, それたけ分子間 の橋かけがより有効に働いてくる。そのため, ゲル含量 は均一采で合成したベースポリマーを用いた場合が, 溶 融素ねり法に比べてきわめて高い值を示す。また，IPP と $\mathrm{MAH}$ との反応の見かけの活性化エネルギーは不均一 系が高温側の MAH の反応中の逃散のために見かけ上は 負となっているのに対して, 均一系での反応はBPOの分
解によるラジカル開始反応であるために $22.9 \mathrm{kcal} / \mathrm{mol}$ という値を示している。さらに橋かけ反応の見かけの活 性化エネルギーについては解離定数を考慮せねばならぬ ためにそれを比較することは無意味であるが，一応，見 かけの活性化エネルギーについて比較してみると，溶融 素ねり反応では反応系の粘度が高いために橋かけの拡散 が反応温度の影響を受け，わずかではあるが，活性化エ ネルギーが計算される。一方, 溶液中での反応は解離し たイオン間の反応であるために，橋かけ剂の拡散は温度 の影響を受けず見かけの活性化エネルギーはほぼ0であ る。また，橋かけに寄与せぬイオン反応生成物の生成量 は溶融素初り反応に比べて反応温度の低い溶液反応では 無視できるぐらいの量である。

さらに合成したポリマーの形状の比較を行ならと, 溶 融素ねり法では一度溶融させるために反応ポリマーは塊 状を呈し，しかも高温のために MAHによる着色が認め られるのに対して, 均一系の場合は美しい白度を有する 粉末状で得られるなどの点が相違点であり, 以上のよう な理由から均一反応によって合成したベースポリマーを 溶液中でイオン橋かけさせる方法がよりすぐれた方法と いえよう。

付 記 : 本報告は第15回高分子討論会 (1966年11月, 大阪)で発表した。

\section{文 献}

1）井手文雄, 釜田和正, 長谷川章：高化, 25, 107(1968)

2）箕浦有二, 大羽希男, 上田 稔：第 12 回高分子研 究発表会講演要旨（1966 年 7 月）

3) 特許： BP 652324 (1963)

\title{
The Reaction of Isotactic Polypropylene with Maleic Anhydride and Ionic Crosslinking of the Obtained Products
}

\author{
II. The Reaction in Solvent
}

by Fumio Ide, *Akira Hasegawa, and Tsuneo Kodama*

As shown by the previous paper, it was possible to introduce the ionic crosslinking into isotactic polypropylene by kneading it with maleic anhydride in molten state. But, in this case, it was not able to avoid deterioration of the polymer. In order to prevent that, we tried to carry out the reaction between isotactic polypropylene and maleic anhydride in solvent. The results were as follows:

1) The reaction between isotactic polypropylene and maleic anhydride homogeneously occurred in xylene at $120^{\circ} \mathrm{C}$, using benzoyl peroxide as the initiator.

2) The deterioration of the polymer was scarcely found.

3) Ionic crosslinking could be introduced in the mixed solvent of toluene and dimethyl formamide, using zinc acetate as the ionic crosslinking agent.

\footnotetext{
* Central Research Laboratory, Mitsubishi Rayon Co., Ltd. (Otake, Hiroshima)
} 